\title{
ALEGORÍA DE LA CLASE MEDIA "REAL" ESPAÑOLA EN MUCHOS HIJOS, UN MONO Y UN CASTILLO
}

Allegory of the "real" Spanish middle class in Muchos hijos un mono y un castillo.

\author{
IRENE DOMINGO SANCHO \\ UNIVERSITY OF ST. THOMAS (ESTADOS UNIDOS) \\ irenedomingo@stthomas.edu http://orcid.org/0000-0002-0626-7414
}

RECIBIDO: 17 DE SEPTIEMBRE DE 2019

ACEPTADO: 16 DE MAYO DE 2020

RESUMEN: Muchos bijos, un mono y un castillo (Salmerón, 2017) es un documental que narra la historia de la vida de su protagonista, Julita, vis a vis la historia de España desde la guerra civil hasta la más reciente crisis económica. La primera aparece en la cinta, además de como madre del director, como alegoría inusual de España en su personificación de la clase media "real" española. En este artículo se analiza cómo Muchos hijos logra visualizar fidedignamente no solo los excesos, sino también las ambigüedades que caracterizan a este sujeto clave en la historia más reciente del país en el ámbito material e ideológico. Atendiendo al formato multi-genérico de la cinta, se estudian las maneras en que los elementos cómicos, trágicos y performativos del documental sitúan a este entre lo carnavalesco y lo crítico humorístico, mientras desvelan las contradicciones muchas veces pasadas por alto, pero fundamentales para entender a la clase que se ha instaurado en el imaginario hegemónico como protagonista de la democracia española.

PALABRAS CLAVE: Alegoría, clase media, ambigüedad, historia, documental.

ABSTRACT: Muchos hijos un mono y un castillo (Salmerón, 2017) is a documentary that narrates the history of its protagonist, Julita, alongside the history of Spain from the Civil War until its most recent economic crisis. Julita appears in the film as the director's mother, and as an unusual allegory of Spain's history thanks to her personification of the "real" Spanish middle class. This article analyzes how Muchos hijos faithfully visualizes not only the excesses but also the ambiguities that characterize the middle class, a key subject in recent Spanish history both on a material and on an ideological level. Paying attention to its multi-generic format, the article will study the ways in which the comic, tragic, and performative elements of the documentary locate the film between carnivalesque and humorous criticism, while they unveil the contradictions oftentimes dismissed but crucial to understand this critical class within the Spanish democratic imaginary.

Keywords: Allegory, middle class, ambiguity, history, documentary. 
"Es el sentimiento del contrario, un Hermes bifronte, una de cuyas caras se ríe de las lágrimas que vierte la otra".

(“Gravedad e importancia del humorismo" Gómez de la Serna, 1930: 368)

Muchos hijos un mono y un castillo, el documental que Gustavo Salmerón estrenó en 2017, es un documental excepcional, en el sentido de que se aleja de lo ordinario. Primero, es excepcional por el gran éxito que ha cosechado desde su estreno entre crítica y público. A la gran cantidad de premios nacionales e internacionales que ha obtenido, se suman las alabanzas de los medios a la película, las ganancias en taquilla y el cariño inmediato de la audiencia a Julita, madre de Salmerón y protagonista de la cinta. ${ }^{1}$ Es excepcional, además, por el hecho de que su director dedicó catorce años de su vida a su rodaje y dos años a su montaje (trabajando con seis montadores, con unas cuatrocientas horas de metraje y llegando a crear unas setenta y cuatro versiones finales diferentes, según Salmerón [Montañez, 2017]). Finalmente, es excepcional por el resultado. El desternillante documental, en sus escasos ochenta y ocho minutos, retrata a la madre del director mientras recorre los últimos ochenta años de la historia de España. El propio Salmerón ha descrito su película en reportajes y en uno de los materiales extra incluidos en el DVD como "un documental sobre la historia de España" realizado "por y para" su madre en el que cada pieza funciona perfectamente dentro del "collage poliédrico de imágenes" que todas ellas construyen y en el que "la comedia está por encima de todo" (Montañez, 2017; Muchos bijos). Aunque la noción de "collage" empleada por Salmerón podría hacer pensar en una cierta anarquía organizativa, la cinta está fuertemente estructurada narrativa, lineal y cronológicamente en torno al paralelismo entre la historia más reciente del país y la biografía de Julita. Esta organización promueve la comprensión de la vida de la protagonista como representativa de la de la nación. Junto con ello, las analogías existentes entre una historia y otra facilitan una interpretación alegórica de Julita. Dicha alegoría, a pesar de ser inusual, como explicaré en este artículo, resulta muy reveladora de la sociedad española actual.

Seguiré a este respecto a Ismail Xavier quien, a la hora de calibrar las alegorías de un texto, pone tanto énfasis en la estructura del mismo como en su recepción dentro de un contexto socio-cultural determinado (2004: 335). Comunes a lo largo de la historia en diferentes géneros, las alegorías han sido tradicionalmente entendidas como procedimientos representativos caracterizados por una mediación a través de la que uno o varios elementos literales (historias, imágenes, personajes) expresan uno o varios sentidos figurados (ideas, conceptos). Para Xavier, los textos que son más susceptibles de una lectura codificada tal son aquellos en los que prevalece la ambigüedad (2004: 340, 343). Este es el caso de Muchos hijos. La ambigüedad, como veremos, surge del trabajo que realiza el documental genéricamente, así como del tema más importante que emerge a lo largo de su visionado: las clases medias. Estas, protagonistas de la historia nacional contemporánea, son representadas en todas sus contradicciones a través de la figura de Julita. En

\footnotetext{
${ }^{1}$ Entre otros, el documental ganó el Goya y el Fénix en 2018 en su calidad de mejor documental. El Ministerio de Educación, Cultura y Deporte reportaba 103.155 espectadores en salas y 589.578,24 € acumulados en septiembre de 2019.
} 
este sentido, y aunque la presencia de las clases medias ha sido siempre muy común tanto delante como detrás de la pantalla en el cine español (de hecho, según la AIMC la mayoría del público que asiste a salas de proyección pertenece a estas clases [2018: 14, 17]), lo que distingue a Muchos hijos es el modo en el que el documental juega con la alegoría hasta componer un fidedigno, por ambivalente, retrato de las mismas. ${ }^{2}$

Para realizar un inicial acercamiento a los mecanismos de que se vale el documental, quiero atender a una de las primeras escenas de la película, la cual fue, no por casualidad, escena elegida también para el tráiler de promoción. En ella se ve a Julita sentada en un sillón, dialogando con su hijo. Este le da directrices acerca de cómo actuar y qué decir; acto seguido ella le pregunta acerca de la viabilidad de su proyecto: "¿Pero cómo va a salir en una película que me he comprado un castillo, porque había heredado, porque yo era una familia normal y luego era súper-rica, pero cómo vas a salir eso?" (sic.) y luego se responde: "Cualquiera que lo vea, que me conozca, dirá, ...pero bueno, es verdad, como es verdad dirán: 'ipues es verdad!', pero no saben lo que ha ocurrido después" (Muchos hijos). La escena es significativa por varias razones. En ella, Julita resume dicharachera y en solo dos frases el arco narrativo básico de la película. Sus palabras la sitúan a ella y a su familia como parte de las clases medias, y anticipan un cambio que va a ser narrado por la película a través del recuerdo. Además, insisten en ese resbaladizo concepto de "verdad" que parece acercar las imágenes del documental a la mímesis, lo cual, no obstante, es inmediatamente después socavado por su "pero". Con esta conjunción adversativa, Julita avanza el elemento de sorpresa que será fundamental dentro de la trama y, a la vez, insinúa la posibilidad de que la cinta incluya elementos que no han estado tradicionalmente relacionados con la supuesta veracidad del documental. No sólo eso, sus palabras establecen también el tono de la misma, cómico pero con un toque trágico. Finalmente, realiza todo ello mientras aparece ante el espectador como un personaje cuya afinidad con la cámara es innegable. Frente a esta, Julita se comporta espontánea y teatrera, excéntrica y lúcida, estrafalaria y profunda, excesiva y llana, honesta y pícara. Su naturalidad así como el estilo de película casera de la cinta, grabada mayoritariamente con cámara en mano, ${ }^{3}$ tiñen de inocencia la escena. Simultáneamente la presencia intrusiva de Salmerón, actor en la vida real y en la escena, y la de Julita, quien, delante de la cámara sigue las instrucciones de su hijo como una veterana y consciente actriz, resalta ambas subjetividades y pone otra vez en entredicho el carácter objetivo del documental. Así, incluso antes de sumergirse en el visionado de Muchos hijos, la audiencia es informada no sólo acerca de su argumento más básico, de su tema y de su tono, sino también acerca de la

\footnotetext{
${ }^{2}$ En $A$ History of Spanish Film Cinema Sally Faulkner recuerda que por razones socio-históricas el cine español trabajó el fenómeno de la movilidad socio-económica en España a partir de los sesenta y que solo una década después empezó a buscar audiencias de las clases medias. Para ella, esta búsqueda transformó la estética del cine y originó películas que se sitúan en un "in-between" en términos de gusto, de forma y de tema, esto es, en un terreno cultural que ella denomina "middlebrow", empleando el término anglosajón (Faulkner, 2013: 2-8). Muchos hijos, no obstante, no se insertaría completamente en esta corriente.

${ }^{3}$ Salmerón grabó con una Mini-Dv, una Super 8 y un iPhone 6.
} 
importancia de la combinación de elementos de la no-ficción clásica, performativos, cómicos y trágicos a la hora de interpretar la obra. ${ }^{4}$

Quienes han reseñado la película han llamado la atención sobre esta hibridación. Quim Casas, por ejemplo, comentaba que la filmación de Gustavo Salmerón "oscila [] del realismo que todo documental debe comportar a un tratamiento de comedia absurda, disparatada" y consideraba "los momentos entre divertidos y bárbaros" como uno de los logros del documental (Casas, 2017). Por su parte, Carlos Boyero indicaba que la cinta "es una comedia durante mucho tiempo, pero también aparece el drama” (Boyero, 2017). Incluso el mismo Salmerón declaró en otra ocasión que la presencia de elementos de géneros tan diversos no había sido un resultado fortuito, sino uno de los objetivos que lo guiaron durante el rodaje. Según él: "Una película tiene que mostrar contradicciones y quería combinar la parte más luminosa con la más oscura" (Belinchón, 2017). Lo interesante de una combinación de rasgos genéricos tal es que, como ha señalado Celestino Deleyto, cada una supone una reconstrucción particular de experiencias socio-políticas (2009: 13). Para el crítico, las películas que participan de varios géneros, impulsando la perpetua evolución y reconfiguración de estos, se pueden establecer también como "el modo más relevante de visualizar ciertos aspectos de la vida" en un contexto cultural determinado (Deleyto, 2009; 14, 13). En esta línea, lo que propongo es leer la mezcla de elementos de géneros tomados de ámbitos tradicionalmente considerados como contrarios: lo serio y lo cómico, lo objetivo y lo subjetivo, como correlato en Muchos hijos de las ambigüedades o incluso, como sugería Salmerón, de las contradicciones que caracterizan a las clases que su protagonista alegoriza y la cinta tematiza.

Al prestar atención a Julita, se observa que su representación se halla infundida de ese sentimiento de lo "contrario" que Ramón Gómez de la Serna identificaba con el "humorismo" a través de la famosa pseudo-cita de Luigi Pirandello reproducida en el epígrafe de este artículo. Como "variedad de lo cómico", el humor mezcla un "tono desenvuelto y jocoso" y "una vena analítica y un mensaje crítico" de tal manera que puede ser simultáneamente normativo y subversivo (Arribas, 1997: 16; King, 2006: 8). ${ }^{5}$ Además, provee una visión distanciada, "oblicua” y desfamiliarizadora que problematiza la objetividad de la representación y hace consciente a la audiencia de los procesos siempre elegidos de acercamiento y comprensión de la realidad (Arribas, 1997: 36-37, 16; Catalá, 2009: 68). A diferencia de lo cómico, sin embargo, como explicó el mismo Pirandello, el humor no consiste en "advertir lo contrario" sino que implica la reflexión y el "sentimiento de lo contrario" que altera el tono de la risa (énfasis en original; 2002: 102). Esta reflexión, según indica Umberto Eco al desarrollar las teorías de Pirandello, surge de la explicitación del contexto en que el objeto de la risa se sitúa (Eco, 1984: 7). Es decir, el humorismo permite que el espectador, aunque observe críticamente y se ría de las carencias de este objeto, en este caso, de Julita, lo haga desde la empatía con el mismo pues entiende que quizá

\footnotetext{
${ }^{4}$ Como indican Elena Oroz y Gonzalo de Pedro Amatria, los editores de La risa oblicua, una de las publicaciones más recientes acerca de los documentales cómicos, la escasez tanto de estudios como de producción de hibridaciones de este tipo se debe al hecho de que el documental ha sido tradicionalmente comprendido como el "correlato fílmico de los discursos de la sobriedad" y la objetividad y, por ello, su intersección con el humor, que "proviene de una forma de ver el mundo" y nunca se encuentra "en la realidad per se", ha sido limitada hasta hace pocas décadas (2009: 20, 26).

5 Todas las traducciones de originales en inglés a lo largo del artículo son mías.
} 
el problema no resida tanto en él como en el contexto en que se sitúa, todo lo cual acerca el texto humorístico a la tragedia (Eco, 1984: 7-8). ${ }^{6}$ Así, Muchos hijos desvela, tras lo cómico y gracias a su vena humorística, la presencia de elementos trágicos también, los cuales son fundamentales para entender la construcción alegórica de su protagonista, así como la ambivalente respuesta de la audiencia, entre distanciada y empática, ante la misma.

A esta reacción contribuye además el hecho de que Muchos hijos no solo navega entre lo serio y lo cómico, sino que lo hace también entre la no-ficción tradicional y el documental performativo. En la línea de la pragmática de J. L. Austin y su definición de los enunciados denominados "performative" en inglés, este modo del documental, como han explicado Susan Scheibler y Stella Bruzzi, está plagado de momentos que más que dirigir la atención a aquello que la película está constatando, la orientan a lo que está simultáneamente realizando (1993: 139-40; 2011: 154). Para Bruzzi es por esto mismo que tanto la presencia de un componente relacionado con la actuación ("performance" en inglés) como la del director son fundamentales dentro de este tipo de documentales. Ambos logran acentuar la inestabilidad inherente al género de la noficción: la continua relación dialéctica que existe entre su aspiración a ser el más fidedigno modo de representar la realidad y el potencial siempre fallido de llegar a ello (2011: 155, 152; 2-7). Como veíamos en la escena antes descrita, el documental de Salmerón trabaja con la actuación de director y protagonista en escena e incluye también otros elementos claramente (auto)reflexivos que subrayan, además de la subjetividad, la artificialidad existente en su representación de la realidad.7 Por ejemplo, el discurso mismo de Julita marca y cuestiona en fracción de segundos la diferencia entre "verdad" y "película". Este juega con elementos como la prolepsis y la metareflexión que captan la atención de la audiencia mientras la distancian de la ilusión de realidad en que puede hallarse inmersa. Conforme termina de hablar, Julita dirige su mirada a Gustavo primero y después, fuera de la pantalla, a la persona o personas que se hallan tras la cámara. Su mirada busca aprobación y esta búsqueda rompe la cuarta pared, acabando de nuevo con cualquier ilusión que pudiera tener el espectador de hallarse ante la pura e inalterada realidad. Mirada y discurso a la par contribuyen al cuestionamiento de aquello que su protagonista llama "verdad" y que va a "salir" en un formato especial, así como de hasta qué punto todo ello se ha visto afectado por las dos personalidades que se ven en pantalla. El juego con la audiencia que manifiestan todas las instancias antes mencionadas es subrayado cuando el "cualquiera que lo vea" de Julita incluye a aquella explícitamente en la escena y, en la misma frase, anticipa su reacción mientras reconoce que le esconde cierta información. De esta manera, con sus elementos performativos, la escena contribuye a poner en entredicho la relación privilegiada que el género ha tenido tradicionalmente con la realidad y desplaza la maestría del conocimiento al espectador (Scheibler, 1993: 136, 146) a quien se dirige e involucra activamente en la decodificación de una historia cuyo significado tendrá que hallarse en la construcción de la cinta e irá, por tanto, necesariamente más allá de la verdad de lo constatado.

\footnotetext{
6 Emplearé los términos "cómico" o "comicidad" y "humor" o "humorístico" siguiendo la distinción de Pirandello y Eco, salvo en los casos en que se trate de referencias o citas a ideas o palabras de otros críticos.

${ }^{7}$ El material extra del DVD, en el que Salmerón aparece entrevistándose a sí mismo y recuerda al espectador la faceta de actor del director, también resalta la perfomatividad de la cinta.
} 
Por ello, retomando lo que exponía al principio de esta introducción, mi análisis de los procesos a través de los cuales Muchos hijos anima a una lectura alegórica de la protagonista partirá de la imposibilidad de comprender el documental como discurso de la seriedad, la objetividad y la verdad -al menos, entendido de la manera tradicional. Primero estudiaré de qué manera Julita es representada como personificación bufonesca y humorística de las clases medias y sus valores, esto es, como objeto de la risa y como fuente de crítica simultáneamente. Luego, en relación con esta duplicidad y la ambivalente respuesta que ella implica, examinaré el formato multi-genérico tragicómico de la cinta y, con este examen, me acercaré a su ataque y alejamiento simultáneo de la realidad histórico-política española recordada y retratada. Todo ello me permitirá iluminar cómo, a través de sus juegos con contrarios, Muchos bijos visualiza de una manera excepcional las contradicciones -tanto en el plano material como en el ideológico- que han definido y todavía definen hoy a las clases medias de las que, no por casualidad, Salmerón y Julita, las dos subjetividades más importantes en la construcción del significado de la cinta, son emblema.

\section{JULITA, ALEGORÍA POCO AL USO}

A Muchos hijos se la ha relacionado con otras obras cinematográficas españolas más o menos recientes en las que una familia matriarcal es el foco principal (Pereda, 2018). Destacan dos. Por su exploración de los avatares de una familia en decadencia que puede leerse de manera simbólica, se la ha definido como "reverso cómico" del documental El desencanto (1976) de Jaime Chávarri (Casas, 2017). Además, Muchos hijos presenta muchas similitudes con Carmina o revienta (2012) de Paco León, director de la misma y, como Salmerón, también actor, e hijo en la vida real de la actriz protagonista. Como en la película de 2012, la de Salmerón tiene como personaje principal a la mater familias, una mujer entrada en edad, gorda, un tanto fuera de lo común, sobrada de desparpajo y comodidad ante la cámara. En ambas películas, esta madre construye la narración con que se organiza la cinta a través de sus monólogos, memorias, testimonios y confesiones. No solo eso sino que, además, a través de estos relatos, las respectivas cintas centralizan dos temas que se vinculan: el de la deuda familiar y el de la muerte, un tema este que ambas tratan con cotidianeidad y humor.

De hecho, gracias al montaje, el relato de Muchos hijos se abre con una referencia de Julita a la muerte ("El día que me muera, vendrá un médico, certificará: 'ha muerto. No le funciona el corazón, lo que sea”" [sic.]) y llega a su conclusión con otra conversación, de nuevo, acerca de la muerte ("Tengo una idea, cuando me esté muriendo, si me muero sola y nadie se entera..." [Muchos hijos]). Este es también tema recurrente a lo largo de la película, pues Muchos bijos está organizada en torno a la búsqueda por parte del director de un hueso humano perdido entre el caos de los objetos que acumula su madre. Así, entre referencia a muerte y referencia a muerte y guiándose por el rastreo de dicho hueso, la película se adentra en los años de infancia, adolescencia y madurez de la protagonista. Mientras descubre quién es Julita, sus deseos, preocupaciones, rutinas y extrañezas, el documental va paulatinamente recordando también el pasado de España desde la guerra civil (Julita nació en 1935), pasando por los años del nacionalcatolicismo de la dictadura, hasta el presente más reciente de la crisis y sus consecuencias. 
Muchos hijos traza con y gracias a Julita y a sus memorias el recorrido de un ascenso económico y su caída. Matriarca de una familia que, como ya anunciaba el tráiler de la película, era de clase "media normal" pero "tampoco era[ ric[a]" (Muchos bijos), la protagonista pasa de la noche a la mañana y, gracias a una herencia de su abuelo, a poder permitirse el tercero de sus sueños, el de gran propietaria: "Ya tenía los hijos, ya tenía el mono...ipues ahora lo que necesitaba era el castillo!" (Muchos hijos). Sin embargo, cuando llega la crisis del 2008 tiene que darlo (a los bancos, se entiende). La entrega del castillo conlleva, además de una afligida pérdida sobre todo para alguien como ella que odia desprenderse de posesiones- una mudanza y, con la mudanza, el traslado de todos los objetos de la familia a un piso. Esto implica mudar, entre otras cosas, armaduras, camas, lámparas y espejos de lujo, así como toda la serie de cachivaches tal que muñecas, dentaduras postizas, cartas de antiguos novios, o recortes de pantalones que Julita diagnosticada familiarmente con el síndrome de Diógenes- ha acumulado durante años y valora por igual. Debido a la ingente cantidad de objetos que la familia tiene en posesión, aquellos que no caben en el nuevo piso de Madrid son trasladados a la fábrica donde trabajaba Antonio, el esposo de Julita. Esta fábrica es una especie de trastero inmenso al que un día alguien entra para robar los objetos más valiosos; ante lo cual la matriarca reacciona con cierta tristeza, pero impertérrita, acopiándose de nuevo de más enseres para el piso. De este modo, al registrar la historia de Julita retrotrayéndose a su nacimiento, pasando por los años de bonanza y llegando hasta las dificultades económicas más recientes, el documental recorre la historia de España, eso sí, encarnada en los sueños y las vivencias de una mujer española de clase media.

A medio camino entre dos posiciones sociales, las clases medias han sido identificadas como protagonistas de la historia de España desde el franquismo hasta el presente. De hecho, tal y como lo ha sintetizado Pablo Sánchez León, incluso antes de la guerra civil, las clases medias fueron el centro del pensamiento liberal pues se consideraba que "encarnaban el interés promotor de la riqueza y la virtud necesaria para el predominio del bien común” (2013: 290). Más adelante, la dictadura franquista logró que se las asemejara "con el conjunto de la sociedad, con el sujeto legítimo de una sociedad desarrollada" a través, entre otras cosas, del "desplazamiento de la producción como eje estructurador de las identidades sociales frente al consumo" y sin tener que proporcionarles las libertades y derechos propios de una democracia (Sánchez León, 2014a: 80, 79). Con la llegada de la transición, las clases medias pasaron a ser, además, el sujeto agente y protagonista socio-político de la democracia. Se asentó la imagen de ellas, por un lado, como el eje pacificador entre las dos Españas enfrentadas en términos socio-políticos y, por otro, como representantes de la libertad en un contexto en que esta palabra se confundía interesadamente con el desarrollo capitalista. Por todo ello, desde que llegó la crisis en el 2008 y, con ella, la "crisis de legitimidad" de la democracia española, tanto las clases medias como el imaginario mesocrático instaurado por la dictadura se vieron fuertemente afectados (Sánchez León, 2014a: 94).

Este cambio que se dio en la estructura y el imaginario social del país como resultado de la crisis no puede explicarse sin atender al hecho de que, como recuerdan Isidro López y Emmanuel Rodríguez, la identificación de la mayoría de los españoles con estas clases medias se ha venido produciendo a través del sueño del desarrollismo franquista por antonomasia: "la vivienda en propiedad" (2010: 469). Esta posesión, basada en la financiarización, aunaba un "cierto nivel de 
consumo", su "acceso a ciertos recursos [públicos] garantizados" y "la centralidad de la familia como medio de integración social" (López y Rodríguez, 2010: 468). Dentro de este contexto, la pérdida de la vivienda y la consecuente deuda han supuesto desde hace años el descubrimiento de la fragilidad que sostiene la generalizada adscripción material y simbólica a las clases medias (López y Rodríguez, 2010: 470). Para muchos españoles la crisis ha comportado la proletarización. Pero esto no ha sido así para sus supervivientes, es decir, para la que López y Rodríguez denominan "la clase media 'real"' (2010: 472). Aquellas personas pertenecientes a esta clase simplemente ha visto intensificada la tradicional contradicción que todavía la identifica. Esta contradicción puede entenderse a la luz de lo que Erik Olin Wright señalaba cuando explicaba que, dentro del mapa de localizaciones basado en la intersección entre relaciones de autoridad y destrezas que es la organización social, las clases medias pertenecen a la clase capitalista y a la clase trabajadora simultáneamente ya que "combina[n] los intereses inherentemente antagonistas del capital y del trabajo" (Wright, 2000: 20). En el caso la clase media "real" española, su contradicción surge del hecho de que su deseo de mantener en pie su frágil adscripción social, como esta está basada en la propiedad y su valor está fundamentado en los mecanismos neoliberales de financiarización, privatización e individualización, choca con su histórica alianza con los trabajadores y su reclamación de derechos públicos, lo cual, según López y Rodríguez, explica su fuerte ambigüedad (2010: 473-74). Esto se traduce, además, en un posicionamiento social mayoritariamente ambivalente pues, ante una posible reconfiguración, esta clase se debate hoy entre un ideal de neomesocracia con sueños plutocráticos globales y una posible cívica y solidaria "resignificación de lo medio" de rango cívico y solidario (Sánchez León, 2015).

Dentro de este marco se entiende a la familia García Salmerón, y a Julita en particular, como pertenecientes - desde la guerra civil hasta el presente- a las clases medias y, más en particular, como veremos, a la clase media "real" de manera ejemplar. En esa escena que describí en la introducción del artículo la misma Julita resumía la manera en la que ella, hija de maestros, profesora en un jardín de infancia, esposa de ingeniero industrial, gracias a una herencia se había comprado un castillo y con esta compra había adquirido antes que nada una deuda que la había identificado sólidamente con las clases medias hasta que la llegada de la crisis desmontó su espejismo, le desveló que su propiedad era en realidad la propiedad de una deuda y, por tanto, que la pertenencia social y la situación económica de ella y del resto de la familia se hallaba más en riesgo de lo esperado. Este, el arco narrativo que configura la biografía de Julita recogida en el documental, permite que la audiencia recorra con ella la evolución histórica de esas clases medias españolas. De la misma manera que Julita es la protagonista del relato de Muchos hijos, las clases medias lo han sido, dentro del relato hegemónico, de la historia contemporánea de España. Así, en este paralelismo entre la historia vital y la nacional, la madre del director se aparece como alegoría un tanto inusual de España en su personificación de esas clases medias acumulativas y contradictorias.

Tanto si son conscientemente creadas como si no, las construcciones alegóricas, como ha explicado Xavier, no se establecen únicamente a través de la narración sino que emergen también de la composición visual (2004: 337). En Muchos hijos, Julita se configura como alegoría singular de las clases medias en el registro mencionado, el de la historia que el documental recorre con ella acerca de su vida y el pasado de España y, además, en el que su excesiva figura encarna. 
Obviamente, la matriarca de los Salmerón no es como el resto de los cuerpos que han solido servir al discurso hegemónico en su función alegórica de la nación. Como es sabido, desde la antigüedad la delimitación de las fronteras ha favorecido esta construcción iconográfica y discursiva de continentes, territorios nacionales, o incluso periodos particulares de la historia como figuras femeninas, en ocasiones, a través de personajes históricos reales, míticos y populares; en otras, con figuras más generales y cotidianas. ${ }^{8}$ El uso de los cuerpos femeninos se debe, como explica María Elena Soliño, a que en culturas con lenguas romance, ellos facilitan la asociación entre la nación y virtudes abstractas tales como la productividad, la libertad, la verdad, la justicia, la heroicidad, o la independencia, cuya simbolización ratifica la adhesión unificada del pueblo al statu quo y al poder (mi énfasis; 2017: 18). Además, como ha señalado Michael Wintle, la fuerza orgánica de estas imágenes opera a la perfección en contextos nacionalistas, y su personificación típica como "joven, bella, inocente y tierna pero noble" funciona de manera productivamente polivalente, pudiéndose cargar de significados ideológicos diversos (2009: 311-12). Julita es una mujer que puede simbolizar perfectamente a España a través de su personificación del conjunto de las clases medias y los valores adscritos históricamente a ellas (la paz, la libertad, la democracia); y sin embargo, la protagonista de Muchos hijos no cumple todos los requisitos pues no es joven, ni bella, ni inocente, ni noble como los cuerpos al uso (mi énfasis). Julita es una mujer mayor, con sobrepeso y con un posible trastorno que le impide desprenderse de bienes y cuya figura se halla, por todo ello, marcada por la desviación de la norma a través del exceso. De hecho, su figura se podría identificar más con la versión moderna del arquetipo del bufón que con cualquiera de las figuras clásicas utilizadas como alegorías nacionales ejemplares.

Si se sigue la sucinta definición de los bufones modernos de Faye Ran se observa que, como ellos, Julita es un ser único físicamente, un personaje mal adaptado tanto por su apariencia como por sus desviaciones de comportamiento y un personaje, además, dual, que evoca reacciones ambivalentes (2007: 25-27). Julita acumula kilos, acumula trastos y acumula años. Dentro del marco del capitalismo neoliberal, esta acumulación es generalmente leída como fracaso e imposibilidad de cumplir con la responsabilidad contraída en los planos público y privado con la sociedad (Meleo-Erwin, 2016: 105). A la vez, no obstante, la acumulación es el valor que la vincula efectivamente a esas clases medias españolas, clases consumistas por antonomasia (mi énfasis). El suyo se trata de un exceso, por tanto, que por un lado alegoriza a la nación a través del impulso capitalista neoliberal en que se basa el imaginario de las clases medias y, simultáneamente, resulta marcado como "falla" dentro de este sistema. En este sentido, como el bufón actual que teorizaba Ran, Julita es un personaje bifronte, "objeto y fuente del humor" porque su impropiedad causa la risa, pero únicamente frente a unas normas reconocidas dadas (2007: 25-27). En otras palabras, si la audiencia se ríe de Julita y con Julita, lo hace porque esta se halla asociada con el carnaval, el mundo al revés y la subversión momentánea de normas y valores y, simultáneamente, incorpora también la vena trágica del humor que analizaba Eco. Si se recuerda, para él, al contrario de lo que ocurre en la comedia carnavalesca, en el humor, aunque el espectador pueda situarse también en una posición de superioridad con respecto al personaje

\footnotetext{
8 Podemos pensar por ejemplo en la construcción en términos únicamente femeninos de Europa, de la misma España, de su Primera y su Segunda República, o en el uso de Atenea, Isabel II, Agustina de Aragón o la Fama, así como de las figuras como la de la madre, la diosa o la matrona para simbolizarlas (Wintle, 2009; Soliño, 2017).
} 
protagonista, siente simpatía hacia él porque lo entiende situado en un contexto que en este caso se explicita y se critica (Eco, 1984: 1-8). Es así que, como consecuencia de sus características bufonescas, la función alegórica de Julita presenta dos facetas: una carnavalesca y una humorística, una que hace advertir "lo contrario" y otra que lleva a su reflexión, una que mueve a la risa jocosa y otra que fomenta la crítica de las normas y valores que la protagonista representa.

En concreto, Muchos hijos inserta constantemente rupturas cómicas desternillantes en las que se subrayan las costumbres, ideas o respuestas estrafalarias, sorprendentes e incongruentes de la madre. E inserta escenas, en relación con ello, en las que su cuerpo y sus usos acumulativos aparecen como perversión de la norma. Así, en varias de ellas se puede ver su gordura, su edad o su almacenamiento denigrados y empleados como diana de una mirada superior, esperpéntica y burlona de la cámara o de otros personajes. La comicidad es en el documental desplegada tanto visual como verbalmente. Varias escenas muestran a Julita desde un plano en picado, un contrapicado o medio plano de tal manera que su cuerpo aparece rodeado de objetos, en el mismo plano que los mismos, compartiendo protagonismo con sus posesiones y presentado, así, como un exceso más, deformado. En otras, la risa surge también de las interacciones entre los personajes, o del choque entre lo que estos dicen y lo que la cámara muestra. Por ejemplo, en una escena rodada frente a una mesa de comedor se ve a uno de los hijos, de pie, amenazando a Julita con la muerte por glotonería mientras ella, sentada e impasible, se come una barra de pan entera: "Tú verás, si te quieres morir, sigue comiendo...Personas de noventa años que tengan sobrepeso, no sobreviven ninguna... Cualquier día revientas... Ya desafía el promedio, pero ya es un atrevimiento plantarle cara a cara a la muerte". Estos momentos presentan a Julita como grotesca figura asociada a "lo bajo" y carnavalesco que, como atípica representación visual de las clases medias, subvierte los valores de compostura, moderación, o productividad con los que, de otra manera, se asociaría España.

A la vez, ese mismo exceso es presentado en muchas otras escenas desde la simpatía, la identificación y la solidaridad. Las tres son facilitadas -al menos entre el público español- por el hecho de que la mayoría, como indicaban López y Rodríguez (2010), se imagina perteneciendo a las clases medias a las que también se adscribe Julita. Son facilitadas, además, por el empleo de un estilo de grabación casero, informal, que resalta la naturalidad y fomenta la verosimilitud de lo que recuenta el sujeto protagonista, acercando emocionalmente la audiencia a esta. Los primeros planos y los planos medios elegidos para las escenas en las que la madre, ya sea sola, ya sea con su esposo o con Gustavo, se desnuda con sus memorias y reflexiones ante la cámara, y el uso del 4:3 de Salmerón para los flashbacks de otros vídeos domésticos previos contribuyen también a esta sensación de inmediatez, proximidad y empatía que siente el espectador con Julita. Y, finalmente, son facilitadas, como estudiaré en la siguiente sección, por el uso de un arco narrativo de orden trágico que incita a la audiencia a verse reflejada en la protagonista o, al menos, a empatizar con ella, pues la lleva a considerar críticamente el marco histórico, social y político en que surge su acumulación. Es por ello que la audiencia se debate en una risa ambivalente que, como en las escenas antes descritas, se dirige a Julita, pero, a la vez, se ríe con ella de ella, pues se ríe de esa España a la que alegoriza a través de su personificación bifronte, bufonesca de las clases medias. 


\section{LA VÉRTEBRA: UNA HISTORIA DE CRÍTICAS Y RISAS}

Salvo el mono y el castillo, por obligación, Julita no da nada. Esta acumulación y los excesos de la protagonista se visualizan constantemente en la pantalla. El horror vacui de su madre lo reproduce Salmerón con unas puestas en escena sobrecargadas de personajes y de cosas. Los objetos, por tanto, tienen un significado en el plano enunciativo y en el realizativo. 9 Para Julita, cada uno es repositorio de toda una serie de memorias y, con ellas, de toda una serie de emociones vinculadas a toda una serie de vivencias de las que no quiere desprenderse: "Tiras parte de tu vida....cada cosa que hay aquí, aunque sea vieja, tiene la vida que tú has dejado en ella y claro ahora pierdes estas cosas y pierdes parte de tu vida", dice la misma Julita [Muchos hijos]). Es decir, estos objetos son más que simples objetos. Ellos contienen y movilizan el recuerdo, revelándose como lo que Jane Bennett, en la línea de Bruno Latour, llamaría un "actante" afectivo. Como los actantes, sus posesiones realizan acciones y transmiten una fuerza de sí a otras entidades (2010: iix, xiii), reconfigurando con cada contacto el afecto que cada posesión despertó en su día y contando de este modo, al unísono y caóticamente, la historia de toda una vida. Así precisamente se lo insinúa Julita a sus hijos cuando estos empiezan a revolver en su armario y le aconsejan reorganizar y tirar: "¿Cómo voy a dejar yo mi vida? Yo mi vida la tengo aquí. Yo no quiero morirme y quedarme sin estos detalles, mira qué monada...” (Muchos hijos). Tal y como ella lo entiende, el sueño de posesión total es el sueño de mantener la vida completamente a disposición; es una manera de evitar el olvido y la propia muerte.

Estos objetos acumulados que instigan y recogen memorias, y que simbolizan momentos concretos de la vida de la protagonista, aluden también a un contexto histórico en particular. Son objetos que establecen un puente entre lo privado y lo social. Funcionan, por tanto, como una suerte de esos lieux de mémoire que Pierre Nora teorizó, como restos que "materializa[n] lo inmaterial" y que sirven para "parar el tiempo, bloquear el trabajo del olvido", archivar y re-leer el pasado desde el presente, "env[olviéndolo] en una cinta de Möebius de lo colectivo y lo individual" (1989: 19). Por un lado, cada uno de los objetos es índice del momento de adquisición, de encuentro, o de recepción. Además, son índices indirectos de un modo cauteloso de enfrentarse a las carencias que la guerra civil y la posguerra, en particular, impusieron en la generación de Julita. Así lo reconoce y explica ella misma en otro de los materiales extra del DVD: "Yo soy feliz porque tengo. Claro. Eso es una cosa propia de la postguerra. Hay que tener cosas por si pasa algo" (Muchos hijos). Y, finalmente, son también índice de ese sueño de acumulación capitalista e individualista que, como explicaba Sánchez León, el franquismo instigó sobre todo a través del ideal mesocrático para borrar las miserias del pasado y ocultar las opresiones del presente (Sánchez León, 2014).

A este respecto, el objeto más importante en Muchos hijos no es el castillo del título, sino una vértebra. Esta se trata del hueso humano perteneciente a la abuela de Julita y perdido en una de las mil cajas acumuladas por esta. Es el hueso cuya búsqueda dio origen a la película y que, por ello, según el mismo director explicaba para El País, vertebra, valga la redundancia, la trama de la

\footnotetext{
9 De nuevo, estoy traduciendo aquí el término "performative" en la línea de Austin que seguían Bruzzi y Scheibler a la hora de estudiar el documental performativo. El término en su traducción permite atender no sólo al plano descriptivo de la historia, sino también al de la construcción y puesta en escena cinematográfica de esta.
} 
misma: "Esta es la historia: En busca de la vértebra perdida. ¡Qué gran título! ¿Cuál es el tema? ¡Qué más da! De la dificultad nacen las grandes obras. Voy a pedir una subvención alegando que esta búsqueda es la búsqueda de España" (Salmerón en Montañez, 2017). La vértebra, además de actante porque dio origen al documental, lo es en su calidad de memento mori para Julita ya que le recuerda a su abuela, asesinada durante la guerra civil española y esto, le lleva a anticipar su propia muerte.

En este sentido, aunque la vértebra es un lieu de la mémoire "íntimamente atado a la vida y a la muerte" (Nora, 1989: 19), es ante todo un lieu que funciona a modo de reliquia. Más que como la magdalena de Proust que Nora traía a colación en su explicación, la vértebra se activa a modo de "objeto material que se relaciona con un individuo particular y/o con los eventos y lugares con los que este individuo estaba asociado" y los condensa a todos "pars pro toto" (Nora, 1989: 15; Walsham, 2010: 11, 12). Julita misma explica: "[L]a tengo [a su abuela] muy asociada a la vértebra ...la veo y luego las vértebras de su cuerpo ... me da miedo. Es que no creas que es lo normal que la gente tenga estas cosas" (Muchos hijos). Incluso antes de ser encontrada, la vértebra y el resto de huesos de la difunta guardados con ella irradian un aura especial (en sentido benjaminiano) para toda la familia: el aura de la abuela, vinculada al momento histórico cuando fue asesinada y que ella hace presente. La vértebra es un objeto especial, por tanto, porque en su calidad de reliquia, en las palabras de Alexandra Walsham, "sublima[...], cristaliza[...] y perpetúa[...] la memoria... conectando el pasado y el presente de una manera concreta y palpable" (2010: 13). En Muchos hijos ella vincula mucho más explícitamente que otras posesiones la historia privada y colectiva que Julita personifica y narra, estableciendo una fuerte conexión entre el pasado de muerte y el presente.

Explica Walsham que las reliquias son "manifestación material del acto de recordar", "una ligazón nemotécnica con un mundo perdido" que evitan que la historia de la cual son un resto, pase al olvido (2010: 13). En el documental, no obstante, más que la vértebra en sí, es la búsqueda de la vértebra la que materializa ese impulso de traer a la memoria la historia de la que ella es índice. La pregunta de Gustavo a Julita: “Dónde están las vértebras?” y las conversaciones entre ambos acerca de la necesidad de encontrar los huesos dan lugar al relato por parte de la madre de la historia de su abuela y, con ella, a la narración del largo impacto de la guerra civil en su propia biografía (Muchos hijos). Así, mientras la búsqueda del director implica un retorno en el tiempo, un recorrido en la memoria familiar y también nacional que se retrotrae a los orígenes genealógicos de la familia tanto en el ámbito privado como en el público, la evocación de la vértebra que esta búsqueda entraña proyecta el recuerdo de Julita directamente a la guerra civil española y sus consecuencias, conectando estas con el presente. De este modo, Muchos bijos construye una narración paralela entre las historias individual y colectiva, y lo hace además performativamente, ya que, no solo constata, sino que también realiza aquello que narra. Por un lado, los diálogos impulsan la historia en la dirección del recuerdo del pasado y por otro, simultáneamente, la cinta misma cumple este acto de luchar contra el olvido que guía a su director y actor en escena ya que su montaje organiza de esa manera lineal cronológica la trama del documental en que y con que se realiza dicha búsqueda.

La ordenación de escenas y secuencias en Muchos hijos en torno a la búsqueda de la vértebra construye una narración que a primera vista tiene un formato de tragedia. A grandes rasgos la 
trama de las tragedias clásicas presentan el siguiente patrón: primero se presenta un estatu quo cuya normalidad es luego alterada por un evento inesperado que implica la caída del héroe. Esta caída había sido anunciada anteriormente por la actitud del héroe quien, a pesar de saber que estaba destinado al fracaso, se empeña en persistir en sus objetivos desmesurados. Esto es lo que se ha llamado la bybris en las tragedias griegas clásicas. La acción se resuelve al final del texto trágicamente, muchas veces con la muerte de dicho héroe, quien, no obstante, se hace consciente en el momento de la anagnórisis de su responsabilidad, de su error o hamartía, en su cambio de fortuna. El relato del documental de Salmerón se abre en la primera mitad de la cinta cuando Julita rememora cómo, dos años después de haber sido asesinada y ocultada bajo piedras cerca del río, todos los huesos de su abuela fueron enterrados en una fosa; todos, salvo aquellos que su marido decidió guardar como recuerdo y que después le dejó en herencia a ella, su nieta, del mismo modo que le dejó toda una fortuna con la que esta se compró el castillo. La historia del asesinato de su abuela invita a Julita a evocar las penurias de la posguerra vivida desde el bando franquista; y le trae a la memoria, a partir de su propia experiencia, el clima de tristeza, muerte y miseria que reinó en España. Junto con ello, Julita recuerda también el cambio de suerte que le llegó con la herencia ("y entonces mira por dónde nos volvimos ricos, ¿y qué hacemos siendo ricos?” [Muchos hijos]) y cómo esta herencia, vinculada a la vértebra y al franquismo a través de su abuelo, le ofreció la posibilidad de cumplir su deseo mesocrático de la vivienda en posesión.

Sin embargo, cuando la familia parecía estar disfrutando de la bonanza y la tranquilidad que su estatus económico y social le aseguraba, un evento inesperado sacude sus vidas. Llega la crisis y la familia pierde el castillo. Así, a partir del minuto 38, casi en la mitad del metraje del documental, Julita empieza a tematizar la ruina familiar, la devolución del castillo y, con ellas, la crisis que asoló a España en el 2008. Estas circunstancias la entristecen y le anuncian su muerte: "[t] engo tantos recuerdos de este rincón [en el castillo]....y me siento interiormente mal ¿eh? De verme que he llegado ya al final". Este cambio de fortuna, no obstante, ya había sido anunciado por parte de Gustavo dentro de la linealidad construida por el documental. Gracias a la organización de las escenas, al principio del largometraje -cuando la familia todavía vivía con comodidad- el director aparece advirtiéndole a su madre de las consecuencias potencialmente fatales de no buscar ni enterrar la vértebra. Entonces le explica: "Los muertos hay que enterrarlos, mamá. Da muy mal karma tener a tu abuela muerta perdida allí por la casa. Hay que buscarlos" y se encuentra con el rechazo por parte de esta de hacer nada al respecto: "No pienso buscarlas. ¡Adiós!”. Luego, una vez pasada la crisis y después de haber hallado de los huesos, se inserta otra escena en que el hijo reincide un poco inútilmente en esta advertencia y se explaya en los detalles de la misma:

-¿Tú sabes que hay una teoría que dice que si no entierras a los muertos, los muertos simbolizan lo material, los huesos simbolizan lo material, y si no los entierras, te arruinas? -¿Ah sí?! pues mira, nos ha venido bien no enterrarlas. —responde Julita irónica— ¡Eso no lo sabía yo, si lo llego a saber...! (Muchos hijos).

Concediendo al entierro y, con él, a la vértebra esos poderes sobrenaturales que normalmente se concede a las reliquias (Walsham, 2010: 13), Gustavo trae a colación en este segundo diálogo una hipótesis que vincula el pasado de la guerra civil y la dictadura -a través de 
la muerte que las vértebras materializan - con el presente de la ruina. Hace esto empleando las vértebras como actantes del recuerdo y como símbolo de esa acumulación material que manifiesta Julita con sus excesos de rango “bybristés” y que, según la teoría a la que apela, está en el origen de las pérdidas económicas que afligen a la familia. Estas pérdidas, como se corresponden dentro de la estructura de la cinta con la reciente crisis española, conectan así, en el plano social de la historia de España a la que Julita alegoriza, la caída económica de la protagonista con la quiebra del imaginario inaugurado por el franquismo; un imaginario basado en la acumulación mesocrática que la vértebra simboliza y que la protagonista, como representación de las clases medias, personifica. De este modo, Muchos hijos hace explícito, a través de su organización de escenas y construcción trágica de la historia de Julita, las causas del cambio sufrido por esta y por el total de las clases medias.

En otras palabras, Muchos hijos trata de dar respuesta con la trama del documental a esa pregunta que Sánchez León planteaba de manera retórica: “¿No es acaso la crisis económica española en su singularidad dentro del panorama mundial la expresión del agotamiento de toda una secuencia histórica presidida por el imaginario mesocrático y sus convenciones morales acerca del bienestar, el estatus y la aquiescencia política?" (Sánchez León, 2014b). Lo que el documental ilumina al mostrar como tragedia paralela la vida de la matriarca y la historia de España es la fragilidad de un sueño de bienestar mesocrático basado fundamentalmente en la financiarización de las posesiones, especialmente la de la propiedad, y lo que esto implica moral e ideológicamente. En este sentido, es interesante prestar atención a la transformación de rango político experimentada por Julita y narrada gracias al montaje del documental.

En la primera mitad se insertan dos escenas significativas. Una en la que Julita apenas puede reconocer los símbolos fascistas todavía presentes en las calles de Cuenca y a cuyos valores su familia se había adscrito; y otra donde explica su afiliación a la Falange en relación al asesinato de su abuela y al signo político de su familia: "[h]ombre, matan a mi abuela, matan a los abuelos del otro, los matan jlos rojos! ....pues nosotros éramos contra los comunistas, contra los rojos, éramos de derechas". En la segunda mitad, es decir, ya pasada la crisis, se incorporan tres escenas de contenido radicalmente diferente. En una se ve a la madre autoproclamarse antimonárquica tras escuchar el discurso del rey Juan Carlos I el día de su abdicación; y, pocos minutos después, masona también. En otra, se la ve denunciar el lucro obtenido por los bancos al aprovecharse de los sueños de pertenencia a clase media por parte de la sociedad española: "Mira, pero todo el mundo lo ha hecho: pobres, medianos y ricos. .... Y resulta que todo el mundo es tonto .... Te daban el dinero muy barato al banco y te lo daban que decías 'bueno, lo invierto en la construcción que me va a dar más'. Pero claro, ha pasao lo que ha pasao" (sic.). En la última, se la ve discutir con su esposo acerca del origen de sus miserias emocionales y económicas y explicarle a este su convicción de que ambas tienen su origen en el levantamiento militar (Muchos hijos).

El cambio que la película historiza así con su montaje, y el que la misma Julita racionaliza dentro de la misma cuando le increpa a su marido: "i $[t]$ ienes que cambiar porque la vida cambia, cambia la naturaleza, cambian las personas y tienes que cambiar!" (Muchos hijos), es una transformación que se presenta no solo como material sino también como ideológica. Lo que Muchos hijos parece sugerir es que, gracias a la búsqueda de la vértebra, al recuerdo que esta incita y a la interpretación de las memorias y la historia evocadas por ella, Julita, que antes vivía 
conforme con el poder, ya no reconoce el levantamiento militar y la dictadura como fondo natural de una posición política dada, sino que intuye en ellos el origen de la crisis que sigue amenazando su posición social y económica. De este modo, la película narra y realiza un viraje que dirige la atención de Julita -y con ella, de la audiencia también- al contexto histórico en el que la protagonista se inserta. Más en concreto, la dirige al sentido común asentado ya en predemocracia sobre la idea de una España libre y pacífica construida al amparo del imaginario de las clases medias y este, a su vez, sobre el espejismo de la propiedad. De ahí que esa acumulación "bybristés" que caracteriza a Julita aparezca ante la audiencia como un rasgo que es risible, pero desde la simpatía. Por eso, esta empatiza con la protagonista y con su error -lo que sería su hamartía, y lo hace porque entiende que las causas de su posible caída fatal se hallan en realidad en el marco ideológico que originó su falla.

\section{DESENLACES VARIOS}

Muchos hijos construye de este modo un arco narrativo trágico en el que, con el viraje y descenso económico, anuncia a la vez la posibilidad del fin vital de Julita y lo que ello simbolizaría en términos del fin histórico no solo del imaginario construido material e ideológicamente sobre las clases medias que ella alegoriza, sino también de estas mismas. Como expliqué antes, la idea de la muerte ronda desde el principio de la película, es retomada con mayor intensidad con la mención de la vértebra en su función de memento mori para la protagonista y se anuncia indirectamente también con el recorrido trágico de su historia. Además, conforme se acerca el desenlace, el documental comienza a acumular referencias a esa defunción de la protagonista que Julita misma anticipaba. Estas parecen corroborar ese final de Julita y de las clases medias, mientras avisan del desenlace próximo del largometraje. El tono tétrico con que se acostumbra a tratar asuntos escatológicos como el de la muerte es, sin embargo, reemplazado en Muchos hijos por uno alegre. Dos escenas en particular son relevantes a este respecto. En la primera aparece Julita recostada sobre una cama vestida de monja, serenada por su villancico favorito, "Noche de paz" y dispuesta a ser pinchada con una aguja que va a comprobar si realmente ha fallecido. Una vez terminado este ensayo del que un día será su entierro, la familia al completo, animada por Julita, se va a merendar. Además de la clara teatralidad de la escena, esta destaca por el choque humorístico que produce entre la seriedad y lo liviano, lo alto y lo bajo, lo excepcional y lo cotidiano.

Un choque similar emerge en la segunda escena, la escena con que se cierra Muchos hijos. En ella, la cámara va acercándose a Julita, de nuevo recostada en cama, hasta llegar a un primer plano. Entonces, animada por su hijo a realizar unas reflexiones a modo de conclusión, la protagonista declara en un tono entre tétrico y juguetón: "No se me ocurre nada, más que se me aproxima el día de la muerte, que tengo 81 años y me veo que me estoy desmejorando, me veo que me estoy volviendo vieja, que no puedo andar, que necesito ayuda...y entonces, ipues quiero divertirme!" (Muchos hijos). Otra vez, la inesperada reacción jocosa de Julita mueve a la risa. Si en la escena anterior parecía abrazar la muerte, pero lo hacía solo como simulacro, en esta, su admisión ante lo inevitable es sustituida por un toque de rebeldía que pone un broche festivo a la película. Así, en su organización temporal de índole teleológica, la vida y la historia que el documental recoge se cierran con el anuncio de la inminente muerte de Julita y del posible fin del 
imaginario y de las clases medias a las que ella personifica, pero elaborado y presentado desde una perspectiva cómica desenfadada.

Tanto en su aspecto formal como de contenido, son dos los fenómenos que convergen en estas escenas. Por un lado, la rebelión de Julita ante la idea de la muerte se presenta desde una posición de lo que Sigmund Freud llamaba "humorista", pues lo que vemos en ambas escenas es su rechazo a sufrir ante "las provocaciones de la realidad" y su empleo de estas provocaciones como fuente misma de placer (1927: 162). A su vez, este placer es transmitido a la audiencia. Esta, habiendo anticipado un resolución de tono lúgubre, es presentada con una ruptura dentro de la congruencia, dentro de la causalidad, dentro de la estructura dada, lo cual, como recuerda Simon Critchley, es una de las fuentes de lo que él también denomina "humor" (2002: 4-10). La risa surge en ambas escenas de la sorpresa que las respuestas de Julita introducen en la normalidad y, a la vez, de la sorpresa que produce el cambio correspondiente en el género del que participa la película: de una trama trágica a una cómica. Al contrario de lo que ocurre en las tragedias donde el héroe encuentra un fin funesto tras haber reconocido cual es el error o bamartía en el origen de su caída, Muchos hijos no concluye de manera amarga, esto es, con la anunciada muerte de la protagonista, sino que su desenlace se acerca más al de una comedia, ya que conlleva el restablecimiento del orden, de la identidad alterada y también una celebración grupal (Johnston, s.f.). 10

Esta celebración aparece, de hecho, una vez finalizado el documental en sí, tras un fundido en negro y antes de los títulos de crédito. Entonces se insertan, a modo de epílogo, nuevos fragmentos de videos caseros en tono sepia con los que se va introduciendo paulatinamente a los miembros de la familia García Salmerón, protagonistas del documental, mientras los muestran más jóvenes disfrutando juntos. Se trata de fragmentos de la misma época y en el mismo color que aquellos que, al principio de la película y gracias al montaje de voz en off de Julita sobre ellos, habían sido localizados durante la época cuando la familia era de clase "media normal". La música de fondo que se escucha sobre estos recuerdos cinematográficos es el estribillo de "Castillos en el aire" de Alberto Cortez. La jovialidad que transmite la canción se halla en consonancia con las reacciones antes descritas de Julita ante la muerte. Por su parte, la letra incide en ese resguardo de los ataques de la realidad que la madre parecía buscar -“y construyó castillos en el aire /... en un lugar a donde nunca nadie / pudo llegar usando la razón"- y que, como sugieren las imágenes elegidas, existe con la familia y en un pasado anterior a la crisis (Muchos bijos). De este modo, el epílogo confirma el tono liviano que las últimas escenas, a pesar de tratar un asunto serio, establecían. En todas estas instancias prevalece una actitud de diversión, fiesta y escapismo ante el triple desenlace: el de la protagonista, el del imaginario de las clases medias y de estas mismas, así como el de la cinta.

Este último, obviamente sí se cumple, pero Muchos hijos ni trabaja la consunción que había insinuado de Julita, ni la de las clases medias y su imaginario. Al contrario, como la protagonista en las últimas escenas, se aleja de esta amenaza y retorna al refugio que fue el periodo de bonanza

\footnotetext{
10 Geoff King resume la problemática en torno a qué rasgos definen el género cómico en su introducción a Film Comedy recordando que el debate se ha centrado en torno a los elementos del final feliz, la risa y las formas narrativas o no narrativas (2006: 5). Todos ellos, reiterando lo teorizado antes, pueden aparecer en un mismo texto cinematográfico.
} 
antes del cambio de fortuna, el periodo de despreocupación previo cuando el estatus socioeconómico de la familia y la sociedad en general no había sido todavía puesto en peligro. A raíz de esto, la risa que surge al final del largometraje no es una risa que apunta a la mentalidad mesocrática que, habiendo sido expuesta y socavada, es rechazada, dada por finiquitada y celebrada. No, se trata de una risa cómica y jocosa que se desentiende de esa realidad y se refugia de ella, socavando parcialmente la crítica al contexto antes establecida. Es una risa que en sus últimos minutos usa a Julita como bufón-objeto de la risa, que reconfigura el texto como entretenimiento momentáneo y que, como el carnaval según Eco, parece, por tanto, validar el statu quo. Como consecuencia, la conexión con la audiencia sufre un corte. Ésta ya no se siente parte de la comunidad simpatizante, compasiva e identificada con la protagonista, sino que simplemente la observa y la reconoce como aquella subjetividad excesiva que ya se había hecho plenamente presente en el tráiler descrito en la introducción.

De hecho, tanto su subjetividad como la del director, vuelven a cobrar relevancia llegados a este punto cuando, justo antes de la escena que cierra la película, se inserta otro fragmento perteneciente a la secuencia de la que se extrajo el fragmento elegido para el tráiler. En él, el discurso de Julita incide de nuevo en el hecho de que aquello que el espectador está viendo se trata de una grabación, en específico una hecha por su hijo acerca de su vida. En esta ocasión, la protagonista explica que si ha aceptado aparecer en el documental ha sido por Gustavo ("ilo que una hace por los hijos!", suspira), ya que le parece que el estilo de grabación no va a ser del gusto de la audiencia: "porque yo tengo una idea más de lo que el público puede gustarle. El público es tremendo. El cine tiene algo más profundo: tiene que tener un guion serio, tiene que tener una buena fotografía...eso es muy complicado" (sic.). Salmerón, por su parte, a quien la cámara muestra sentado junto a su madre con la caja de las vértebras en el regazo, justifica las críticas diciendo que va a ser su "primera película larga" (Muchos bijos). En su diálogo, las reflexiones acerca del formato de la película tienen un efecto distanciador. La audiencia ve su atención dirigida a la performatividad y, con ello, a la artificialidad de la cinta. Junto con la actuación de madre e hijo, protagonista y director, sus palabras resaltan la intención artística que existe detrás de lo que de otro modo se presentaría como un documento inalterado de la realidad. Además, hacen hincapié en el hecho de que son, en realidad, dos los personajes a cargo de la construcción de la película pues esta ha ido configurándose en la interacción entre director y protagonista. Finalmente, recuerdan que son también dos los rasgos que mejor caracterizan, ya no solo a Julita, sino también a Gustavo, portador ahora de las vértebras: la acumulación y una intensa contradicción.

Y es que, al final del documental se hace obvio que, como Julita, su hijo recoge y acapara en su descomunal grabación todos esos objetos y esas memorias de las que su madre no quería desprenderse (y que llevó del castillo al piso, y del piso a la fábrica). Él es, de hecho, el heredero de la más preciada de las posesiones, la vértebra ("Ya estás heredao" le dice su madre, prometiéndole el hueso [sic., Muchos hijos]) y, como tal, receptor de lo que esta implica. O sea, efectiva y simbólicamente Salmerón recoge en y con su documental los excesos que definen a su madre. Como esta también, y aún sabiendo de los peligros, implicaciones y connotaciones ideológicas de la acumulación, Salmerón reproduce el gesto que llevó a esta a la ruina en un intento similar por mantener viva la vida, por evitar la muerte y por no olvidar, entre otras cosas, 
los antecedentes de dicha quiebra. Si este gesto es contradictorio, también lo es aquel de huida despreocupada con el que ambos reaccionan ante una crisis cuyos orígenes conocen, cuyo impacto saben que fue desastroso para muchos y que sigue amenazándolos. Al llegar los minutos finales de Muchos hijos, tanto el trabajo de Salmerón como su madre y protagonista eluden con jovialidad la misma amenazante realidad que en un principio encaraban críticamente.

La ambivalencia ideológica que subsecuentemente transpira la cinta no puede desvincularse del hecho de que esos dos rasgos: la acumulación y la contradicción son índices de las clases medias que el documental tematiza. De hecho, más en concreto, son índices que localizan a Julita y a Gustavo dentro de esa clase media "real" española que López y Rodríguez estudiaban (2010: 472). Esta es una clase que, como la familia García Salmerón, aunque se ha visto afectada por la crisis, no ha sido completamente arruinada y, por tanto, ni se ha visto en la posición de peligro real de proletarización que otros grupos sí han experimentado, ni ha tenido que hacerse completamente consciente de la importancia que una respuesta con miras al futuro de rango ético supondría. Es así que, cuando llegado el desenlace de Muchos bijos se da una mudanza en la comicidad, en el arco genérico y en la perspectiva desde la que se acerca a la realidad la película, dicha mudanza habla del recorrido histórico y, también, de la posición social actual de las dos subjetividades que el documental nos recuerda como capitales en la construcción de su significado, tanto en el plano enunciativo como en el realizativo. Es una mudanza que, de este modo, suspende en la ambigüedad la alegoría de la clase media "real" que había venido trabajando. Por un lado, estudia y ataca, desde la simpatía con el mismo, la acumulación que materializa el cuerpo de Julita, al cual presenta como personificación del imaginario mesocrático y de la vida de la mesocracia que se normativizó en España con el franquismo (y que sigue presente). Por otro, una vez lo ha criticado, se desentiende de sus implicaciones, se ríe sin contexto y se instala en la normalidad acomodaticia del pasado. Como consecuencia, tiñe la risa del documental de tonos ambivalentes: por momentos crítica y por momentos jocosa; humorística en ocasiones y, en ocasiones, carnavalesca. Y de esta manera refleja la tensión que estructura a la clase media "real" que Muchos hijos tematiza.

En conclusión, a través de su mezcla de elementos performativos y otros típicos del documental tradicional, de su organización del montaje para crear una trama que participa de la tragedia y de la comedia, de su trabajo con los excesos bufonescos de Julita y los correspondientes elementos humorísticos y carnavalescos, de su índice al contexto en que se inserta, su subversión, pero su final re-establecimiento del orden, Muchos hijos hace visibles las ambigüedades materiales e ideológicas que caracterizan a la clase media "real" actual que la misma Julita personifica. Así, al trabajar la relación dialéctica entre su aspiración a ser el más fidedigno modo de representación de la realidad y el potencial siempre fallido de llegar a ello (Bruzzi, 2011: 2-7), el documental de Salmerón acaba representando la realidad española histórica, social, económica y política de manera fidedigna, a pesar de su artificio. Por tanto, podría decirse incluso que, además de mostrar sus ambigüedades y presentarla como un clase contradictoria, lo que el documental consigue es exponer a esta clase media "real" como una clase fuertemente paradójica. ¿Por qué? Porque la alegoría que el documental trabaja revela, con esa mezcla de contrarios aparentemente contradictorios que la recorren a ella y a la cinta, una 
profunda verdad acerca de esta figura tan importante para entender España hoy. Lo que Muchos bijos visualiza, como su decodificación ha demostrado, es la ideología y la materialidad de una clase vertebrada en la tensión entre la ansiedad de su posible caída y su rechazo en última instancia a enfrentarse a la realidad que todavía la amenaza, así como a imaginar alternativas que podrían llegar incluso a transformarla. 
BIBLIOGRAFÍA

AIMC (Asociación para la Investigación de Medios de Comunicación) (2018), Marco general de los medios en España. Madrid: AIMC, D.L.

ARRIBAS, Inés (1997). La literatura de bumor en la España democraática. Madrid: Pliegos.

BELINCHÓN, Gregorio. "La mujer que perdió un castillo pero ganó una película”. ElPaís (2017).

BennetT, Jane (2010). Vibrant Matter: A Political Ecology of Things. Durham: Duke University Press.

BOYERO, Carlos. "A sus pies, surrealista Julita”. ElPaís (217).

BRUZZI, Stella (2011). New Documentary: A Critical Introduction. London: Routledge.

CASAS, Quim. ““Muchos hijos, un mono y un castillo’: la familia Salmerón”. ElPeriódico (2017).

CATALÁ, Josep (2009). "Límites de lo risible: ética y estética del documental humorístico”. Oroz, Elena y de Pedro Amatria, Gonzalo (eds.). La risa oblicua: Tangentes, paralelismos e intersecciones entre documentaly humor. Madrid: Ocho y medio, Libros de cine: 45-74.

CHÁvArRI, Jaime (1976). El desencanto. España: Manga Films.

CRITCHLEY, Simon (2002). On Humor. New York: Routledge.

Deleyto, Celestino (2009). The Secret Life of Romantic Comedy. New York: Manchester University Press.

Eco, Umberto (1984). "The Frames of Comic Freedom”. Sebeok, Thomas A. (ed.). Carnival!. New York: Mouton Publishers: 1-10.

FAulKner, Sally (2013). A History of Spanish Film. Cinema and Society. 1910-2010. London : Continuum Publishing.

FrEUD, Sigmund (1927). "Humor". Freud, Sigmund (ed.). The standard edition of the complete psychological works of Sigmund Freud. Volume XXI (1927-1931): London: Hogarth Press: 159-166.

GÓMEZ DE LA SERNA, Ramón. "Gravedad e importancia del humorismo". Revista de Occidente 89 (1930): 348-391.

GuERRA, Andrés. “'Muchos hijos, un mono y un castillo': la historia de una familia surrealista y tres deseos". La Vanguardia (2017).

JOHnStOn, Ian. "Dramatic Structure: Comedy and Tragedy”. (s.f.).

KING, Geoff (2006). Film Comedy. London: Walflower Press.

LEÓN, Pablo (2012).Carmina o revienta. España: Cameo.

LÓPEZ, Isidro y RODRíGUEZ, Emmanuel (2010). Fin de ciclo. Financiarización, territorio y sociedad de propietarios en la onda larga del capitalismo hispano (1959-2009). Madrid: Traficantes de Sueños. 
MeleO-ERWIN, Zoë, "Queering the Linkages and Differences (Fat and Disability)". Pausé, Cat; Wykes, Jackie y Murray, Samantha (edas.) (2016). Queering Fat Embodyment. London: Routledge: 100-118.

MINISTERIO de educación, cultura y deporte. "Ficha de Muchos hijos, un mono y un Castillo" (s.f.).

MontAÑEZ, Beatriz. “El 'show' de Julita y familia”. El País Semanal (2017).

NORA, Pierre. “Between Memory and History: Les Lieux de Memoire”. Representations 26 (1989): $7-24$.

Oroz, Elena y DE Pedro Amatria, Gonzalo (2009). "La risa oblicua o cuando el humor desvió al documental de su rígido canon". Oroz, Elena y de Pedro Amatria, Gonzalo (eds.). La risa oblicua: Tangentes, paralelismos e intersecciones entre documental y humor. Madrid: Ocho y medio, Libros de cine: 19-44.

PEREDA, Olga. “ 'Muchos hijos, un mono y un castillo': los sueños chalados de Julita”. El periódico (2018).

PIRANDELLO, Luigi: "Esencia, caracteres y materia del humorismo". CIC: Cuadernos de información y comunicación 7 (2002): 95-130.

RAN, Faye (2007). "Modern Tragycomedy and the Fool". Robb, David (ed.). Clowns, Fools, and Picaros: Popular Forms in Theatre, Fiction, and Film. Amsterdam: Rodolpi: 25-36.

SALMERÓN, Gustavo (2017). Muchos hijos, un mono y un castillo. España: Cameo.

SÁnCHEZ LeÓn, Pablo. “Avatares de un régimen de clases medias”. La Circular (2015).

SÁNCHEZ LEÓN, Pablo (2013). "Decadencia y regeneración. La temporalidad en los conceptos fundamentales de la modernidad española”. Fernández Sebastián, Javier y Capellán de Miguel, Gonzalo (eds.). Santander: Editorial de la Universidad de Cantabria: 271-300.

SÁNCHEZ LEÓn, Pablo. "Desclasamiento y desencanto. La representación de las clases medias como eje de una relectura generacional de la transición española". Kamchatka 4 (2014a): 63-99.

SÁNCHEZ LEÓn, Pablo. "Desclasamiento y desencanto. Representaciones de clase media y poética de la participación democrática en la transición española”. Presentación Seminario Euraca (2014b).

SCHEIBLER, Susan (1993). "Constantly Performing the Documentary. The Seductive Promise of Lightning Over Water”. Renov, Michael (ed.). Theorizing Documentary. New York: Routledge: 135-150.

SOLIÑO, María Elena (2017). Mujer, alegoría y nación : Agustina de Aragón y Juana la Loca como construcciones del proyecto nacionalista español (1808-2016). Madrid: Iberoamericana.

Walsham, Alexandra. "Introduction: Relics and Remains". Past and Present 5 (2010): 9-36.

Weinrichter, Antonio (2004). Desvíos de lo real. El cine de no ficción. Madrid: T\&B Editores. 
WintLE, Michael (2009). The Image of Europe. Visualizing Europe in Cartography and Iconography throughout the Ages. Cambridge: Cambridge University Press.

Wright, Erik Olin (2000). Class Counts: Comparative Studies in Class Analysis. Cambridge: Cambridge University Press.

XAVIER, Ismail (2004). "Historical Allegory". Miller, Toby y Robert Stam (eds.). A Companion to Film Theory. Malden: Blackwell Publishing Ltd. 333-362. 